\title{
The Reproductive Organs of the Herring in Relation to Growth.
}

\author{
By \\ V. C. Wynne-Edwards, B.A., \\ Student Probationer at the Plymouth Laboratory.
}

With 4 Figures in the Text.

THE different organs of an animal do not all grow at one speed. Some develop precociously, and others, like the reproductive system, are delayed for a considerable time in their development, though ultimately they may become very large. In a mature herring about one-fifth of the entire weight consists of reproductive tissues. The different organgrowths are integrated into the growth of the whole body, and one kind of curve will represent both the parts and the whole.

In the herring there are great seasonal changes consequent upon spawning. The weight of the gonads reaches a maximum and then falls abruptly to zero, after which it increases again to the next maximum at the following spawning season. The amplitude of this fluctuation is an increasing one; and, at the suggestion of Dr. J. H. Orton, I have made the following analysis to discover whether a time comes ultimately when the increasing tax of spawning brings about the animal's death. If the successive gonad-maxima go on increasing after the general bodygrowth has slowed down, this may be the case; on the other hand, if the growth-rate of the gonads is not greater than that of the body in old fishes, it may be assumed confidently that death is due to other causes.

While at Port Erin in 1925 I made a series of weighings and agedeterminations which provided data exactly suited to the investigation of this point, on which this paper is based.

\section{Material.}

The samples of herrings used fall into two series, one from the Irish Sea within a radius of twenty miles of the Chickens Lighthouse, to the south of the Isle of Man, locally called Calf Herrings; the other from inshore shoals off Port Erin bay, known as Low Herrings, which spawn slightly earlier. The principal part of this paper deals with the Calf 
samples, which were more numerous and extend over the whole spawning season. They were obtained from Scottish steam-drifters at Port St. Mary between August 18th and September 25th, 1925.

Within a few hours of landing the fish were measured and weighed, the gonads removed and weighed also. At the same time scales taken

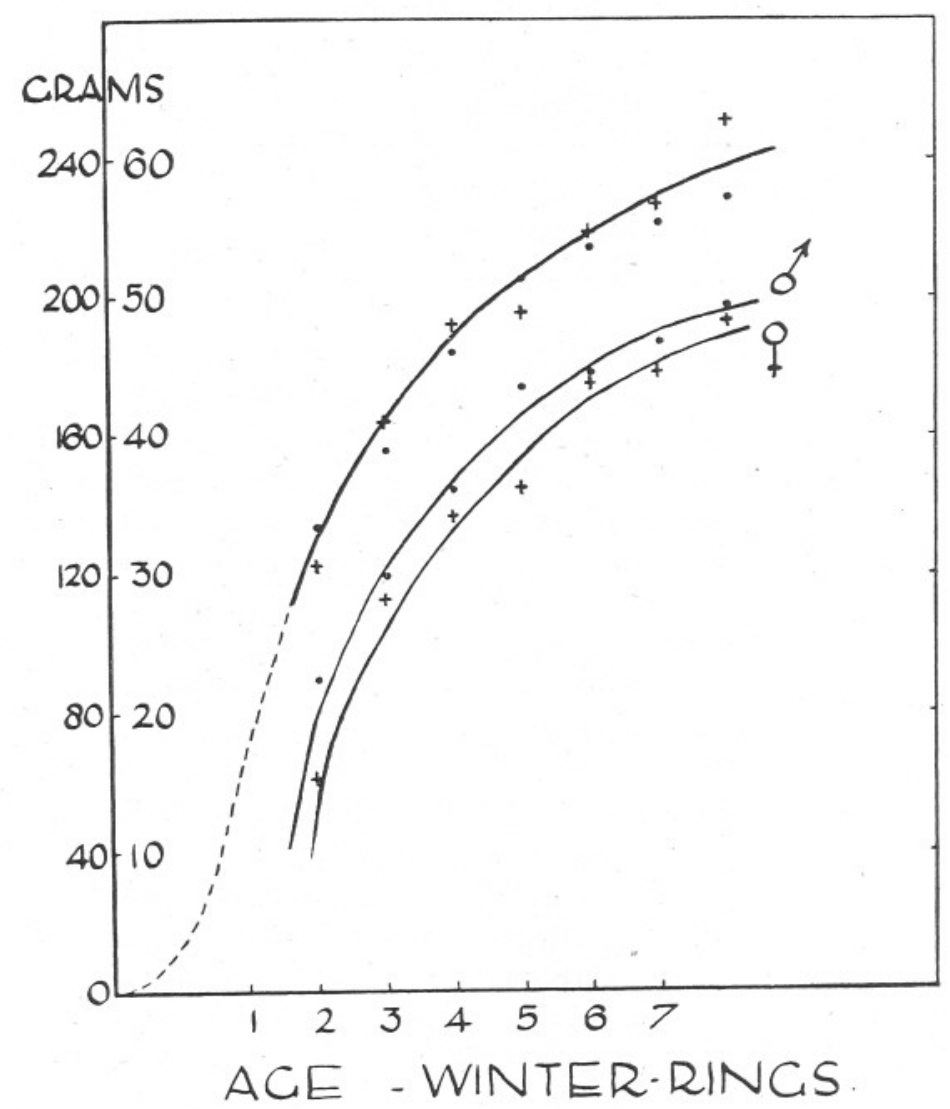

FIG. 1.-Total Body-Weights (upper curve) and Gonad-Weights (lower curves) of Calf herring, plotted against age.

Data for males represented by dots, and for females by crosses.

from each fish were placed in numbered watch-glasses, and from these age-determinations were made. Scales with more than seven dark winterrings were regarded as unreliable in age-determination, and have been disregarded in curve-fitting.

Fish in other than stages V and VI of maturity could not of course be used, and this, together with the separation of the sexes, reduces the data materially. Tests have been made, however, to show that where 
conclusions have been drawn, they are mathematically justified. The fact that the curves are not smooth does depend to some extent upon the numbers available, but also very largely on the natural diversity of different year-classes of herrings from the same shoals. From the numbers of each year-class obtained by sampling it is clear that different years offer different chances of survival at least, and probably also of growth ; complete homogeneity would not be realized, however great the sample might be.

\section{Age-frequency of Calf Herrings.}

$\begin{array}{lccccc}\text { Year of birth } & 1918 & 1919 & 1920 & 1921 & 1922 \\ \text { Frequency } & 83 & 83 & 54 & 61 & 80\end{array}$

Subsequent sections refer to the Calf samples, unless otherwise stated.

\section{BODY-WEIGHT.}

The rate of growth is at its maximum when the fish is about two years old ; that is, the point of inflexion of the S-shaped growth-curve occurs at this time. Consequently all the material considered here is situated in the upper portion of the curve, where the growth-rate is continually decreasing. This growth-curve is similar to that of autocatalysis, and has been studied by Pearl (3). No attempt has been made here at curvefitting, so that it is not possible to say whether the growth of the two sexes can be represented by a single curve, or whether they form two distinct curves. It appears from Fig. 1 that they are, at any rate, very close together, if not identical. The females attain a greater weight in these samples, and apparently a greater age also.

\section{GoNAD-WEIGHT.}

The growth of the gonads, like that of any other organ, can be represented by a curve similar to that for the whole animal. In Fig. 1 the curve for gonad-weight is on four times the scale of the body-weight curve. The former is displaced to the right, owing to the initial delay in gonad development, and is at first steeper than the body-growth curve, but after about seven years (five winter-rings) it maintains a fairly constant relation to the body-weight.

The gonad curve is really discontinuous once spawning has occurred for the first time. At this and subsequent spawning times the gonadweight falls abruptly to zero, whence it re-develops to reach the next datum on the curve in the following season (Fig. 2). These successive maxima fall on a smooth curve which is independent of the total weight of the body.

The gonads are not the only organs which undergo an annual cycle. 
Mr. E. Ford has kindly placed at my disposal extensive data on the liverweight of the mackerel, which passes through a similar cycle, the maxima appearing just before the spawning season. These maxima also lie on an S-shaped curve. Owing to the difficulty of catching herrings of the same class at all seasons of the year, no investigation has been made of the changes which take place in other tissues of the body, except just before and during the spawning season (Bruce, 1). It appears, however, that even the muscle tissue is depleted to some extent at this time, and that its growth may also be represented by a rhythmic curve with rising

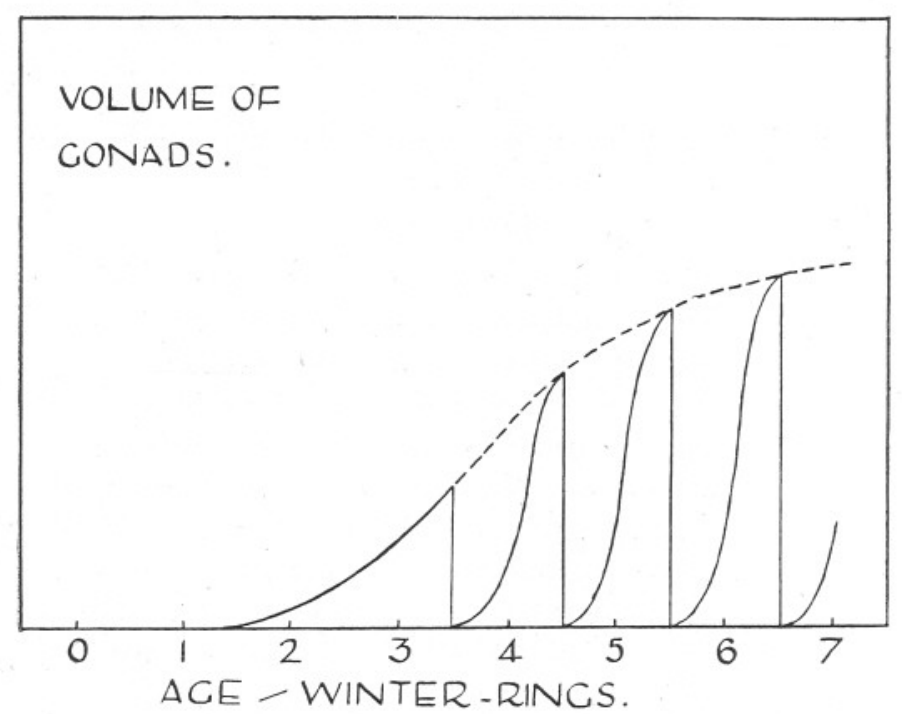

FIG. 2.-Diagram illustrating the discontinuity of gonad development.

maxima. Thus at least two periodic fluctuations are taking place in the body, whose amplitudes are independent. The total body-weight represents the sum of a differential system of organ-growth.

\section{Relation of Gonad-weight to Body-weight.}

The data were divided into weight-groups at $10 \mathrm{gm}$. intervals. The figure given for the weight is the mid-point of the group, and differs slightly from the mean within the group (Tables V and VI). In Figs. 3 and 4 it will be seen that the points, though somewhat scattered, show a high correlation between gonad-weight and total body-weight, and that the line which fits the points most closely is nearly straight, The correlation coefficients which are worked out below, approach sufficiently near to unity to enable a straight line to be used as a working approximation. 
The relation which is important here is that of gonad-weight to bodyweight. Subsequently it will be necessary to deduce approximate gonad-weights from body-weights, so that the line to be determined is the regression of gonad-weight on body-weight. Gonad-weight is the dependent and body-weight the independent variate. This relation, called the regression function, is given by the formula (Fisher, 2) :--

$$
y=\bar{y}-b(x-\bar{x}),
$$

where $y$ is the gonad-weight with mean $\bar{y}, x$ is the total body-weight with mean $\bar{x}$; and $b$ is a constant to be determined, called the regression coefficient. It gives the slope of the curve.

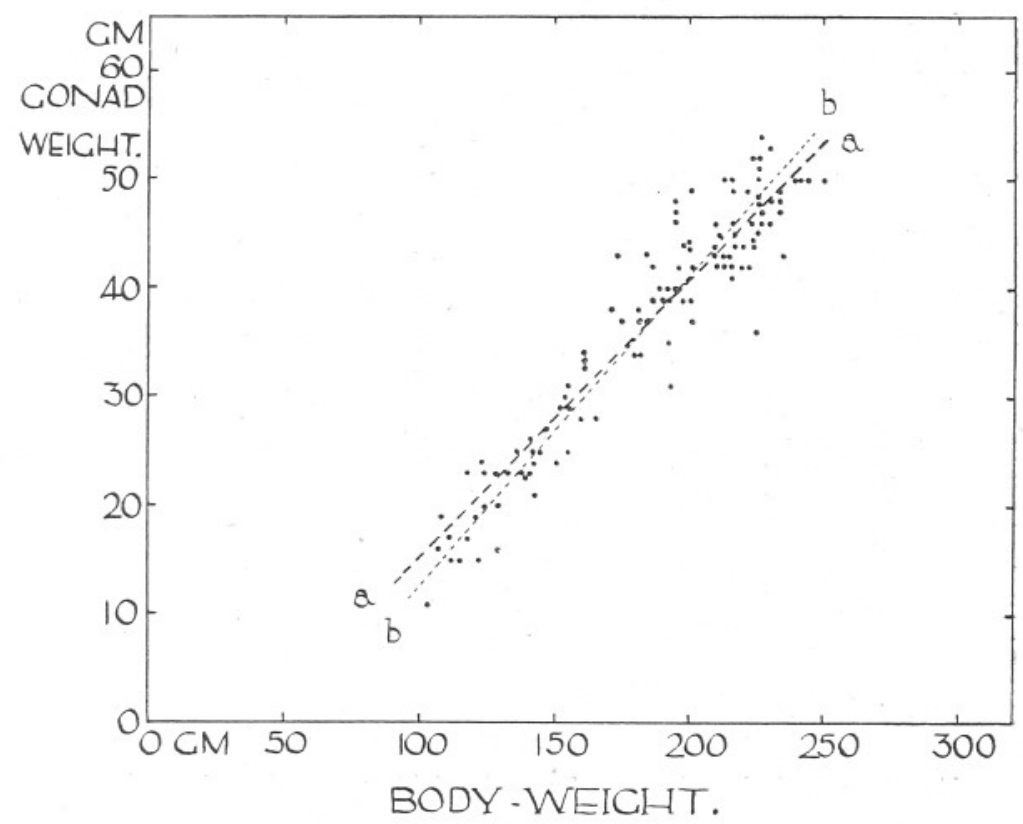

FIG. 3.-Correlation diagram of gonad-weights and body-weights for males of Calf type.

aa. Regression line of gonad-weight on body-weight.

bb. Regression line of body-weight on gonad-weight.

It is important to notice that the regression of body-weight on gonadweight is not the same as the regression of gonad-weight on body-weight. It would be if the correlation between the two variates were complete (i.e. unity), which it is not. In Figs. 3 and 4 both regression lines are drawn, illustrating the difference. The fact that the regression line evaluated and used below does not appear to fit the points perfectly is liable to deceive unless this distinction is realized. 
For the males it is found that

$$
\begin{array}{ll}
\sigma_{y}= \pm 2 \cdot 189 \times 5 \mathrm{gm} . & \bar{y}=37.26 \mathrm{gm} . \\
\sigma_{x}= \pm 3.973 \times 10 \mathrm{gm} . & \bar{x}=186.5 \mathrm{gm} .
\end{array}
$$

The coefficient of correlation $(r)$ between $y$ and $x$ is $0 \cdot 949$. The regression coefficient $(b)$ is estimated by the formula

$$
b=r \frac{\sigma_{y}}{\sigma_{x}}=0 \cdot 949 \times \frac{2 \cdot 189 \times 5}{3.973 \times 10}=0 \cdot 261
$$

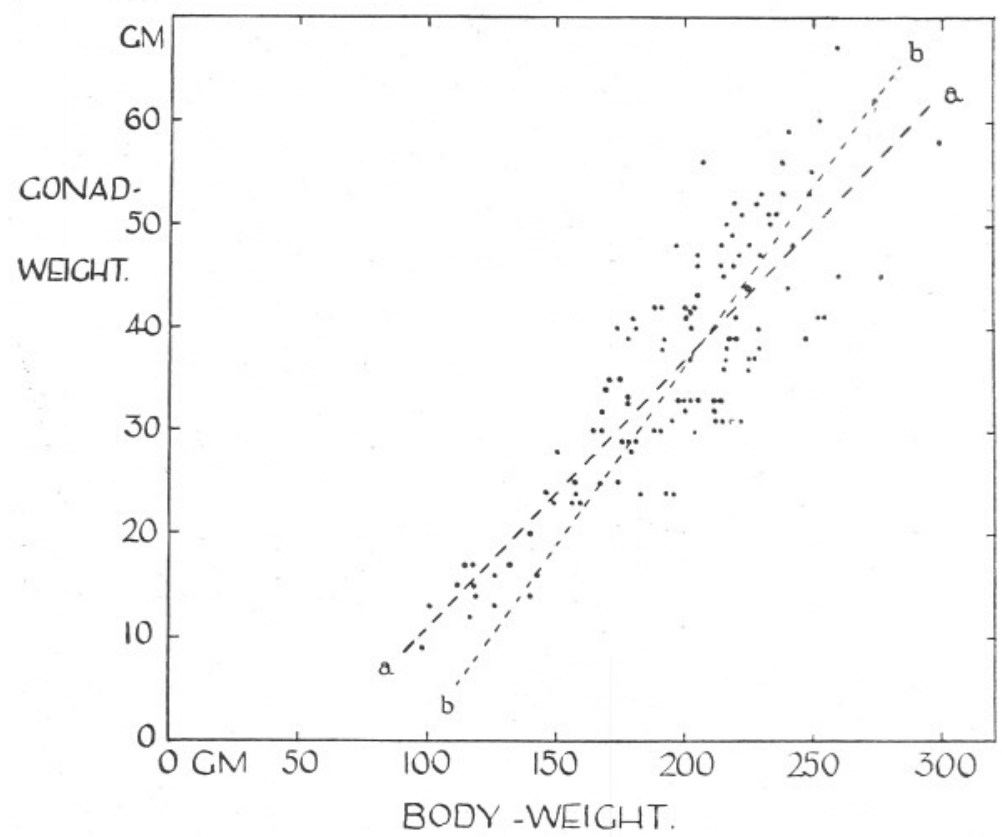

Frg. 4.-Correlation diagram of gonad-weights and body-weights for females of Calf type.

Lettering as in Fig. 3.

Therefore

$$
\begin{aligned}
y & =37 \cdot 26+0 \cdot 261(x-186 \cdot 5) \\
& =0 \cdot 261 x-11 \cdot 5 \mathrm{gm} .
\end{aligned}
$$

For the females,

$$
b=r \frac{\sigma_{y}}{\sigma_{x}}=0.876 \times \frac{(2.407 \times 5)}{(3.959 \times 10)}=0 \cdot 266
$$

Therefore

$$
\begin{aligned}
y & =36 \cdot 33+0 \cdot 266(x-197 \cdot 25) \\
& =0 \cdot 266 x-16 \cdot 2 \mathrm{gm} .
\end{aligned}
$$


Though the very close agreement between the regression coefficients of males and females may be fortuitous, there cannot possibly be a significant difference between the two growth-rates. The constants 11.5 and $16 \cdot 2$, which indicate how far the lines are displaced to the right along the $x$-axis, differ by nearly $5 \mathrm{gm}$., and it will be necessary to test the significance of this.

Two 25-gm. groups of values were selected where the mean total weights of males and females are the same.

Take $x=222 \cdot 5 \mathrm{gm}$. (range of weight from 213-237 gm.).

TABLE I.

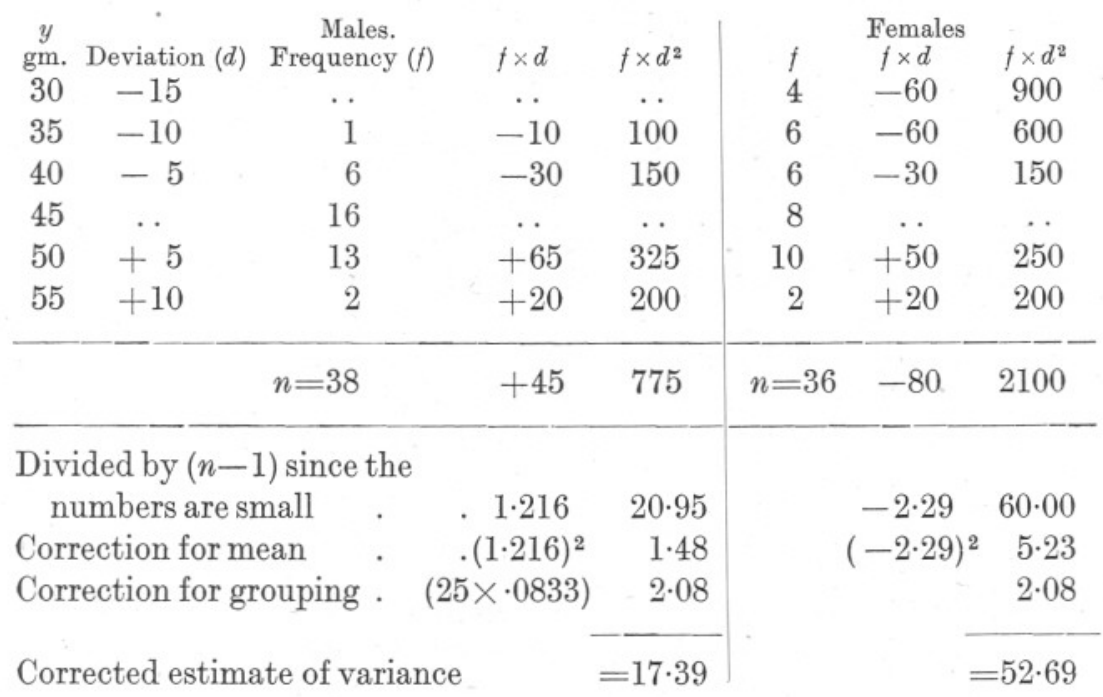

Standard Error of the means of $y_{1}$ (males) and $y_{2}$ (females) $=s$.

$$
\begin{aligned}
& s^{2}=\frac{17 \cdot 39}{38}+\frac{52 \cdot 69}{36}=0 \cdot 458+1 \cdot 463 \\
& \therefore s=\sqrt{1 \cdot 92} 1= \pm 1 \cdot 39 \mathrm{gm} . \\
& \text { Mean } y_{1}=46 \cdot 22 \mathrm{gm} . ; \text { and mean } y_{2}=42 \cdot 71 \mathrm{gm} . \\
& \therefore y_{1}-y_{2}=3 \cdot 51 \mathrm{gm} .
\end{aligned}
$$

Thus in this case the mean difference between testes and ovaries is about $3.5 \mathrm{gm}$. The points therefore lie closer together than the average (4.7 gm.) ; yet this difference is about 2.5 times its own standard error, so that it may be regarded as definitely significant.

Taking two other pairs of values, where $x=199 \mathrm{gm}$., we find the 
difference of the mean gonad-weights to be $6 \mathrm{gm}$., with a standard error of $1.56 \mathrm{gm}$. $P$ is therefore rather more than 0.0001 , which means that such figures could be explained by coincidence in only one out of ten thousand trials, assuming the samples to be random.

The mean gonad-weights of the whole sample (o $37 \cdot 26$, ㅇ $36 \cdot 33 \mathrm{gm}$.) differ by less than a gram. For this reason it might still be thought that the male and female regression lines of gonad-weight on body-weight are virtually identical. Such confusion arises from the fact that, though the ovaries are lighter than the testes in comparable fishes, the females reach a greater absolute size. The range of ovary weight is thus extended beyond that of testis weight, bringing the mean relatively higher. The total body-weights at which the mean gonad-weights occur (o 186.5, o $197.2 \mathrm{gm}$.) make this clear.

Since the regression functions are used extensively in the following pages, and considerable importance attaches to their reliability, tests have been made to show whether or not the departures from straightness of the lines are significant. These are given in an appendix at the end of the paper. I have to thank Dr. R. A. Fisher for his assistance at this point. His methods have been used throughout this paper, and the sums and calculations are drawn up as nearly as possible on the lines of the examples given in his book (Fisher, 2). In both sexes of the Calf herring which have been tested, the probability of any departures from linear regression being significant is well below the formal limit (5 per cent.).

\section{Conclusions from Regression Functions.}

Certain deductions may be made from this analysis. The males and females have been found statistically distinct in so far that the testes occupy a greater proportion of the total weight than do the ovaries in comparable fishes. The rates of growth of the gonads with respect to body-weight are, however, the same.

The regression lines obtained are approximations to the facts over the range considered. It is not legitimate to produce them to cut the $x$-axis at 44 and $61 \mathrm{gm}$., since the real lines are certainly not straight as will be shown below. It is clear, however, that the female gonads lag behind the male at the initiation of development, a lag indicated by $61-44 \mathrm{gm}$. For if the two sexes were simultaneous in this respect, either the regression lines would be identical, or they would diverge from a common initial point, with different regression coefficients. This is contrary to the observations made previously.

Nor can the observed sexual difference be due to a difference in specific gravities of testicular and ovarian tissue. If this were the case, the coefficients $b_{1}, b_{2}$ could not be the same. The regression lines would 
again diverge for increasing values of $x$, even if they did not have a common origin.*

If the regression equation is applied to the sigmoid gonad curve in Fig. 1, it will be seen how the approximation breaks down if extended beyond the range of observations. By putting successively $y=0, x=0$, we should have a curve asymptotic to -11.5 at the lower end, and reaching the value $0 \mathrm{gm}$. when $x=44.0 \mathrm{gm}$. (for the males). This is of course impossible, but it is easily shown that the origin of the curve is near this point, when $x=41 \mathrm{gm}$. For instance, if the ratio $\frac{y}{x}$ is calculated, the observed ratios are less than the theoretical values at first, which is to be expected if the origin of the real curve is near this point.

\section{TABLE II.}

$\begin{array}{ccccccc}\text { Age (winter rings) } & 2 & 3 & 4 & 5 & 6 & 7 \\ \text { Observed } \frac{y}{x} \% & 16 \cdot 46 & 18 \cdot 9 & 19 \cdot 4 & 21 \cdot 2 & 20 \cdot 7 & 21 \cdot 06 \\ \text { Theoretical } \frac{y}{x} \% & 17 \cdot 4 & 18 \cdot 7 & 19 \cdot 9 & 20 \cdot 5 & 20 \cdot 7 & 20 \cdot 9\end{array}$

The gonads thus start to develop in the summer after the first winter ring is laid down, when the males reach a weight of 35 to $50 \mathrm{gm}$. It is possible that the females have reached a greater size at this time, which would account for the initial difference in gonad-weight, or that the development of their gonads may be delayed somewhat longer. Spawning fishes were not found amongst the Manx herring less than $95 \mathrm{gm}$. in weight, or having scales with fewer than two winter rings.

\section{"Low" Herrings.}

In confirmation of these results, data obtained from samples of the inshore or Low herring have been examined in the same way. The data are not so extensive as those for the Calf type, and were collected rather before the height of the spawning season, from July 21st to 29th. They comprise 234 fish, of which 161 were in Stage V, and thus available for comparison with the other samples; 110 were males, and 51 females.

In the same way as before the regressions of gonad-weight on bodyweight have been determined. These are not thought to be very reliable,

\footnotetext{
* The specific gravities of the fresh gonads of six male and six female herrings about to spawn (Stage V) have been determined from Plymouth material. If anything, the testes are lighter than the ovaries. Sp. Gr. of Testes $=1 \cdot 07(5) ;$ Sp. Gr. of Ovaries $=1 \cdot 08(4)$.
} 
particularly in the case of the female, but they offer an excellent check upon those found for the other data. The regression functions are :-

for the males,

$$
y=0 \cdot 21(7) x-10 \cdot 45 \mathrm{gm} .
$$

and for the females,

$$
y=0 \cdot 21(9) x-20 \cdot 3 \mathrm{gm} .
$$

These are also statistically distinct. The coefficients are again almost the same, though the very slight difference observed is certainly due to coincidence. They are considerably smaller than the same coefficients in the Calf samples, due largely to the earlier stage of maturity found in the present case. Stage $\mathrm{V}$ is elastic, embracing for $200 \mathrm{gm}$. fishes a range of male gonad-weight between 30 and $50 \mathrm{gm}$. ; for this reason there is a notable difference between the earlier and final grades of ripeness found within it.

AGE.

The rate of growth of the gonads decreases with advancing age; and in this sense their increase can be correlated with the number of times the fish has spawned. The more numerous the spawnings, the smaller the annual increase of gonad-weight. Such a correlation would, however, be a false one ; for the growth-rate of the gonads is intimately concerned with that of the whole body, which also becomes smaller with advancing age. There is no other connection with the number of spawning seasons. For, if a number of fish of the same weight are taken, their ages will vary over a small range; and it is possible to show that among these the older fish, which have spawned more often, have gonads just as large as, and no larger than the younger ones, allowances being made for the variations of different year-classes. A comparison of fishes of roughly the same weights, but of different ages, is the only method of approach to this question.

In the following Table the two 25-gm. weight groups (200 and $225 \mathrm{gm}$.) have been combined to illustrate this point. The range of weight is from 188 to $237 \mathrm{gm}$. The mean observed ratio $\frac{y}{x}$ is given, and also the theoretical ratio, calculated from the regression formulæ. The differences between these are slight, and there is no marked increase in the observed values in the older year-groups, such as would be expected if the size of the gonads went on increasing after the general growth had practically ceased.

It may be noticed in addition that the material annually spent in building up the gonad is completely made up before the next season.

For four years after spawning the relative size of the gonad continues to increase (see Table on p. 57); there it remains almost constant, and its actual weight increases in linear proportion to the body-weight. 
The end of these four preliminary seasons, during which the relative fecundity is rising, is not a turning-point in the death-rate, as far as can be ascertained from the numbers in these and subsequent year-classes.

TABLE III.
Age (winter rings) 3
4
5
6
$78 \&$ above

MaLes

$\begin{array}{lcccccc}\text { Frequency } & - & 7 & 21 & 20 & 9 & 4 \\ \text { Observed } \frac{y_{\mathrm{O}} \%}{x} & - & 19 \cdot 8 & 20 \cdot 9 & 20 \cdot 8 & 21 \cdot 2 & 20 \cdot 9 \\ \text { Expected } \frac{y_{\mathrm{O}}}{x} & - & 20 \cdot 4 & 20 \cdot 7 & 21 \cdot 0 & 20 \cdot 9 & 21 \cdot 1 \\ \text { Difference } & - & -0 \cdot 6 & 0 \cdot 2 & -0 \cdot 2 & 0 \cdot 3 & -0 \cdot 3\end{array}$

Females

$\begin{array}{lcccccc}\text { Frequency } & 2 & 8 & 14 & 22 & 12 & 3 \\ \text { Observed } \frac{y}{x} \% & 18 \cdot 3 & 17 \cdot 0 & 18 \cdot 9 & 19 \cdot 6 & 18 \cdot 9 & 17 \cdot 7 \\ \text { Expected } \frac{y}{x} \% & 18 \cdot 2 & 18 \cdot 2 & 18 \cdot 7 & 19 \cdot 0 & 18 \cdot 9 & 19 \cdot 1 \\ \text { Difference } & 0 \cdot 1 & -1 \cdot 2 & 0 \cdot 2 & 0 \cdot 6 & 0 \cdot 0 & -1 \cdot 4\end{array}$

TABLE IV.

$\begin{array}{lccccccc}\text { Age (winter rings) } & 2 & 3 & 4 & 5 & 6 & 7 & 8 \text { \& above } \\ \text { Frequency } & 80 & 61 & 54 & 83 & 83 & 36 & 37\end{array}$

Both five- and six-ring groups are particularly numerous.

Thus it appears that spawning does not draw on the resources of the fish to a greater extent than can be replaced, with interest, each year. There is no indication of an increasing tax which the fish cannot make up, the effects of which continue to pile up until ultimately they cause its death, in a way that has sometimes been suggested. The growth of the gonads is in harmony with that of the other organs.

There is a notable difference in the absolute sizes of the two sexes. For the Calf type, the mean weight of the females is $197 \cdot 25 \mathrm{gm}$., and for the males $186.5 \mathrm{gm}$. This, however, does not approach the great difference 
found in the flat-fishes or the whiting. Owing to the uncertainty of agedetermination when the rings become crowded, it is not possible to say whether the females attain a greater age also.

I wish to thank Mr. E. Ford for his constant advice, and Dr. R. A. Fisher, F.R.S., for his kindness in going over the manuscript.

\section{SUMMARY.}

From two series of samples of different populations of herrings from the neighbourhood of the Isle of Man, data were obtained of the lengths, weights, gonad-weights, and ages of 396 mature fishes. The growths of the whole body and of the gonads were represented by the upper portions of S-shaped curves. The male and female body-weights are nearly the same at any age over the range considered, but the testes of the male are always heavier than the ovaries of the female in such comparable fishes. The females attain a greater size than the males.

The weight of the gonads bears a linear relationship (as a first approximation) to the total weight of the fish over the range of size considered. The regression functions evaluated for the two sexes are

$$
\begin{aligned}
& y=0 \cdot 261 x-11 \cdot 5 \text { for the males, and } \\
& y=0 \cdot 266 x-16 \cdot 2 \text { for the females, }
\end{aligned}
$$

where $y$ is the gonad-weight and $x$ the total weight of the fish, both in grams. The difference between the weights of testes and ovaries in male and female fishes of the same size is therefore about $4.7 \mathrm{gm}$., which is shown to be significant. It cannot be due to specific gravity of growthrate differences, since the regression coefficient $(0 \cdot 26)$ is the same for both sexes.

It is suggested that the reproductive organs start to develop in the summer following the laying down of the first winter ring on the scales; and that the initial handicap in female gonad-weight may be due to the males being smaller than the females at this time.

Confirmation of the conclusions drawn from the Calf herring is given by a similar analysis of the Low herring samples.

By a comparison of fishes of the same weight but of varying ages, it is shown that the annual loss of tissue at spawning is completely made up during the next twelve months, and that death cannot be due to the increasing tax of spawning ultimately exceeding the animal's powers of recovery.

\section{REFERENCES.}

1. Bruce, J. R. Biochemical Journal, 18, Nos. 3 and 4, 1924.

2. Fisher, R. A. Statistical Methods for Research Workers. 2nd Ed., Edinburgh, 1928.

3. Pearl, R. Studies in Human Biology. Baltimore, 1924. 
TABLE V.

Correlation Table of Gonad-weight and Total Body-weight for Males of the "Calf" Type.

\begin{tabular}{|c|c|c|c|c|c|c|c|c|c|c|c|c|c|c|c|c|c|c|c|}
\hline 1 & 105 & 115 & 125 & 135 & 145 & 155 & 165 & 175 & 185 & 195 & 205 & 215 & 225 & 235 & 245 & 255 & Total. & $\begin{array}{c}\text { Frequency } \\
\times \\
\text { Deviation. }\end{array}$ & $\begin{array}{c}\text { Frequency } \\
\times \\
\text { (Deviation) }^{2} \text {. }\end{array}$ \\
\hline $\begin{array}{l}10 \\
15 \\
20 \\
25 \\
30\end{array}$ & $\begin{array}{l}1 \\
1 \\
1\end{array}$ & $\begin{array}{l}4 \\
1\end{array}$ & $\begin{array}{l}2 \\
3 \\
3\end{array}$ & 4 & $\begin{array}{l}1 \\
6\end{array}$ & $\begin{array}{l}2 \\
4\end{array}$ & 2 & & & 1 & & & & & & & $\begin{array}{r}1 \\
7 \\
5 \\
16 \\
7\end{array}$ & $\begin{array}{r}-5 \\
-28 \\
-15 \\
-32 \\
-7\end{array}$ & $\begin{array}{r}25 \\
112 \\
45 \\
64 \\
7\end{array}$ \\
\hline 35 & & & & & & & 3 & 1 & 4 & 1 & 1 & & 1 & & & & 11 & 0 & 0 \\
\hline $\begin{array}{l}40 \\
45 \\
50 \\
55\end{array}$ & & & & & & & & $\begin{array}{l}1 \\
1\end{array}$ & $\begin{array}{l}4 \\
1\end{array}$ & $\begin{array}{l}6 \\
3 \\
1\end{array}$ & $\begin{array}{l}2 \\
4 \\
1\end{array}$ & $\begin{array}{l}5 \\
7 \\
3\end{array}$ & $\begin{array}{l}2 \\
8 \\
7 \\
1\end{array}$ & $\begin{array}{l}3 \\
3 \\
1\end{array}$ & 3 & 1 & $\begin{array}{r}20 \\
27 \\
19 \\
2\end{array}$ & $\begin{array}{r}20 \\
54 \\
57 \\
8\end{array}$ & $\begin{array}{r}20 \\
108 \\
171 \\
32\end{array}$ \\
\hline $\begin{array}{l}\text { Total }-n p \\
\text { Total excess } \\
\text { Mean excess } \\
\text { Product } \\
\text { Frequency }\end{array}$ & $\begin{array}{c}3 \\
-12 \\
-4 \cdot 000 \\
48 \cdot 00\end{array}$ & $\begin{array}{c}5 \\
-18 \\
-3 \cdot 600 \\
64 \cdot 80\end{array}$ & $\begin{array}{l}8 \\
-23 \\
-2 \cdot 875 \\
66 \cdot 12\end{array}$ & $\begin{array}{c}4 \\
-8 \\
-2 \cdot 000 \\
16 \cdot 00\end{array}$ & $\begin{array}{l}\quad 7 \\
-15 \\
-2 \cdot 143 \\
32 \cdot 14\end{array}$ & $\begin{array}{c}\quad 6 \\
-8 \\
-1 \cdot 333 \\
10 \cdot 67\end{array}$ & $\begin{array}{c}5 \\
-2 \\
-0 \cdot 400 \\
0 \cdot 80\end{array}$ & $\begin{array}{c}3 \\
+3 \\
+1 \cdot 000 \\
3 \cdot 00\end{array}$ & $\begin{array}{c}9 \\
+6 \\
+0.667 \\
4 \cdot 00\end{array}$ & $\begin{array}{c}12 \\
+14 \\
+1 \cdot 167 \\
16 \cdot 33\end{array}$ & $\begin{array}{c}8 \\
+13 \\
+1 \cdot 625 \\
21 \cdot 12\end{array}$ & $\begin{array}{c}15 \\
+28 \\
+1.867 \\
52 \cdot 27\end{array}$ & $\begin{array}{c}19 \\
+43 \\
+2 \cdot 263 \\
97 \cdot 31\end{array}$ & $\begin{array}{c}7 \\
+19 \\
+2.714 \\
51.57\end{array}$ & $\begin{array}{c}3 \\
+9 \\
+3 \cdot 000 \\
27 \cdot 00\end{array}$ & $\begin{array}{c}1 \\
+3 \\
+3 \cdot 000 \\
9 \cdot 00\end{array}$ & $\begin{array}{c}115 \\
+52 \\
0 \cdot 4522 \\
23 \cdot 51\end{array}$ & +52 & 584 \\
\hline $\left.\begin{array}{c}\times \\
\text { Deviation } \\
\text { Frequency }\end{array}\right\}$ & -24 & -35 & -48 & -20 & -28 & -18 & -10 & -3 & $\mathbf{0}$ & 12 & 16 & 45 & 76 & 35 & 18 & 7 & +23 & & \\
\hline $\left.\begin{array}{c}x \\
\text { (Deviation) }^{2}\end{array}\right\}$ & 192 & 245 & 288 & 100 & 112 & 54 & 20 & 3 & 0 & 12 & 32 & 135 & 304 & 175 & 108 & 49 & 1829 & & \\
\hline$n_{p}(x-\bar{x})(y-\bar{y})$ & 96 & 126 & 138 & 40 & 60 & 24 & 4 & -3 & , & 14 & 26 & 84 & 172 & 95 & 54 & 21 & 951 & & \\
\hline
\end{tabular}

NoTE.-All calculations are made in grouping units, i.e. 10 grams for $x$ and 5 grams for $y$. 


\section{TABLE VI.}

Correlation Table of Gonad-weight and Total Body-weight for Females of the "Cale" Type.

\begin{tabular}{|c|c|c|c|c|c|c|c|c|c|c|c|c|c|c|c|c|c|c|c|c|c|c|c|c|}
\hline & 100 & 110 & 120 & 130 & 140 & 150 & 160 & 170 & 180 & 190 & 200 & 210 & 220 & 230 & 240 & 250 & 260 & 270 & 280 & 290 & 300 & \multicolumn{2}{|c|}{$\mid \begin{array}{l}\text { Frequency } \\
\text { Total } \times \\
\text { Deviation }\end{array}$} & $\begin{array}{c}\text { Frequeney } \\
\times \\
\text { (Deviation)2 }\end{array}$ \\
\hline 10 & 1 & 1 & 1 & 3 & & & & & & & & & & & & & & & & & & 2 & -10 & 50 \\
\hline $\begin{array}{l}15 \\
20\end{array}$ & 1 & 1 & & 3 & $\begin{array}{l}2 \\
1\end{array}$ & & & & & & & & & & & & & & & & & 11 & $\begin{array}{l}-44 \\
-3\end{array}$ & 176 \\
\hline 25 & & & & & & 2 & 4 & 4 & 1 & 1 & 1 & & & & & & & & & & & 13 & $\begin{array}{l}-3 \\
-26\end{array}$ & $\begin{array}{r}9 \\
52\end{array}$ \\
\hline 30 & & & & & & $\overline{2}$ & & 3 & 2 & 2 & 3 & 3 & 2 & & & & & & & & & 17 & -17 & 17 \\
\hline 35 & & & & & & & & 2 & 5 & & 4 & 3 & 2 & 3 & & & & & & & & 19 & 0 & $\mathbf{0}$ \\
\hline $\begin{array}{l}40 \\
45 \\
50 \\
55 \\
60 \\
65\end{array}$ & & & . & & & & & 1 & 3 & 4 & $\begin{array}{l}5 \\
1\end{array}$ & $\begin{array}{l}2 \\
1\end{array}$ & $\begin{array}{l}3 \\
3 \\
4\end{array}$ & $\begin{array}{l}3 \\
4 \\
4 \\
2\end{array}$ & $\begin{array}{l}1 \\
2 \\
2 \\
1\end{array}$ & $\begin{array}{l}3 \\
2 \\
1\end{array}$ & 1 & 1 & 1 & & 1 & $\begin{array}{r}22 \\
12 \\
12 \\
6 \\
4 \\
1\end{array}$ & $\begin{array}{r}22 \\
24 \\
36 \\
24 \\
20 \\
6\end{array}$ & $\begin{array}{r}22 \\
48 \\
108 \\
96 \\
100 \\
36\end{array}$ \\
\hline Total & 2 & 1 & 5 & 3 & 3 & 4 & 4 & 10 & 11 & 7 & 14 & 9 & 14 & 16 & 6 & 6 & 2 & 1 & 1 & 0 & 1 & 120 & +32 & 714 \\
\hline Total excess & $\begin{array}{c}-9 \\
-4\end{array}$ & -4 & -21 & -12 & -11 & -6 & -8 & -10 & -1 & 0 & +3 & +4 & +19 & +31 & $\begin{array}{r}+21 \\
\end{array}$ & +16 & +8 & +5 & +2 & 0 & +5 & +32 & & \\
\hline $\begin{array}{l}\text { Mean excess } \\
\text { Product }\end{array}$ & $\begin{array}{c}-4 \cdot 500 \\
40 \cdot 50\end{array}$ & $\begin{array}{c}-4 \cdot 000 \\
16 \cdot 00\end{array}$ & $\begin{array}{c}-4 \cdot 200 \\
88 \cdot 20\end{array}$ & $\begin{array}{c}-4 \cdot 000 \\
48 \cdot 00\end{array}$ & $\begin{array}{c}-3 \cdot 667 \\
40 \cdot 33\end{array}$ & $\begin{array}{c}-1 \cdot 500 \\
9 \cdot 00\end{array}$ & $\begin{array}{c}-2 \cdot 000 \\
16 \cdot 00\end{array}$ & $\begin{array}{c}-1 \cdot 000 \\
10 \cdot 00\end{array}$ & $\begin{array}{r}-0 \cdot 091 \\
0.09\end{array}$ & $\begin{array}{l}0 \cdot 0 \\
0 \cdot 0\end{array}$ & $\underset{0.64}{+0.214}$ & $\begin{array}{c}+0.444 \\
1.78\end{array}$ & $\begin{array}{l}1 \cdot 357 \\
25 \cdot 78\end{array}$ & $\begin{array}{l}1 \cdot 937 \\
60 \cdot 05\end{array}$ & $\begin{array}{l}3 \cdot 500 \\
73 \cdot 50\end{array}$ & $\begin{array}{l}2 \cdot 667 \\
42 \cdot 67\end{array}$ & $\begin{array}{r}4 \cdot 000 \\
32 \cdot 00\end{array}$ & $\begin{array}{l}5 \cdot 000 \\
25 \cdot 00\end{array}$ & $2 \cdot 000$ & 0.0 & $\begin{array}{l}5 \cdot 000 \\
25 \cdot 00\end{array}$ & $\begin{array}{l}0 \cdot 2667 \\
8 \cdot 533\end{array}$ & & \\
\hline$\underset{\times}{\text { Frequency }}$ & \}$_{-20}^{40.50}$ & $\begin{array}{r}1600 \\
-9\end{array}$ & $\begin{array}{r}88 \cdot 20 \\
-40\end{array}$ & $\begin{array}{r}48 \cdot 00 \\
-21\end{array}$ & $\begin{array}{r}40 \cdot 33 \\
-18\end{array}$ & $\begin{array}{r}9 \cdot 00 \\
-20\end{array}$ & $\begin{array}{r}16 \cdot 00 \\
-16\end{array}$ & $\begin{array}{r}10 \cdot 00 \\
-30\end{array}$ & $\begin{array}{r}0 \cdot 09 \\
-22\end{array}$ & $\begin{array}{l}0 \cdot 0 \\
-7\end{array}$ & $\begin{array}{c}0.64 \\
0\end{array}$ & $\begin{array}{l}1 \cdot 78 \\
+9\end{array}$ & $\begin{array}{l}25 \cdot 78 \\
28\end{array}$ & $\begin{array}{c}60.05 \\
48\end{array}$ & $\begin{array}{c}73.50 \\
24\end{array}$ & $\begin{array}{c}42 \cdot 67 \\
30\end{array}$ & $\begin{array}{l}32 \cdot 00 \\
12\end{array}$ & $\begin{array}{c}20 \cdot 00 \\
7\end{array}$ & $\begin{array}{c}4.00 \\
8\end{array}$ & $\begin{array}{l}0.0 \\
0\end{array}$ & $\begin{array}{c}20.00 \\
10\end{array}$ & $\begin{array}{l}8.633 \\
-27\end{array}$ & & \\
\hline $\begin{array}{l}\text { Deviation } \\
\text { Frequency }\end{array}$ & & & & & & & & & & & & & & & & & & & & & & & & \\
\hline $\begin{array}{c}\times \\
(\text { Deviation })^{2}\end{array}$ & \} 200 & 81 & 320 & 147 & 108 & 100 & 64 & 90 & 44 & 7 & 0 & 9 & 56 & 144 & 96 & 150 & 72 & 49 & 64 & 0 & 100 & 1901 & & \\
\hline$n_{p}(x-x)(y-\bar{y})$ & 90 & 36 & 168 & 84 & 66 & 30 & 32 & 30 & 2 & 0 & 0 & 4 & 38 & 93 & 84 & 80 & 48 & 35 & 16 & 0 & 50 & 986 & & \\
\hline
\end{tabular}

Nore.-All calculations are made in grouping units, i.e. 10 grams for $x$ and 5 grams for $y$. 


\section{APPENDIX.}

These tests of the straightness of the regression lines follow the method given by Fisher (2, pp. 216-223). The steps of the calculation are arranged consecutively, and are intended to be read in conjunction with Dr. Fisher's book. where a similar case is described in full. Tables 50 and 51 in his example correspond to Table V for the males and Table VI for the females in mine.

(a) Males.

$$
\begin{array}{cccc} 
& \multicolumn{2}{c}{\text { TABLE VII }} & \\
& \text { Estimate. } & \begin{array}{c}
\text { Correction } \\
\text { for Mean. }
\end{array} & \begin{array}{r}
\text { Corrected } \\
\text { Estimate. }
\end{array} \\
\Sigma(y-\bar{y})^{2} & 584 & -\frac{52^{2}}{115} & 560 \cdot 5 \\
\Sigma(x-\bar{x})^{2} & 1829 & -\frac{23^{2}}{115} & 1824 \cdot 4 \\
\Sigma(x-\bar{x})(y-\bar{y}) & 951 & -\frac{52 \times 23}{115} & 940 \cdot 6
\end{array}
$$

From Table V,

Sum of Products in first 16 arrays $=520 \cdot 14$

\begin{tabular}{|c|c|c|c|}
\hline Variance. & $\begin{array}{l}\text { Degrees of } \\
\text { Freedom. }\end{array}$ & $\begin{array}{l}\text { Sum of } \\
\text { Squares. }\end{array}$ & $\begin{array}{l}\text { Mean } \\
\text { Square. }\end{array}$ \\
\hline Between Arrays & 15 & $496 \cdot 6$ & . \\
\hline Within Arrays & 99 & $63 \cdot 9$ & $0 \cdot 645$ \\
\hline Total & 114 & $560 \cdot 5$ & \\
\hline$\therefore[\Sigma($ & $\begin{array}{r}\Sigma(x-\bar{x})( \\
\frac{\left.\sum(y-\bar{y})^{2}\right]}{\sum(x-\bar{x})^{2}}=\end{array}$ & $\begin{array}{l}\bar{x})^{2}=1 \\
\bar{y})= \\
\frac{40 \cdot 6)^{2}}{324 \cdot 4}=\end{array}$ & \\
\hline
\end{tabular}

Product in final array $\quad=23.51$

From Table VII,

$$
\begin{aligned}
\Sigma\left[n_{\mathrm{p}}\left(\bar{y}_{\mathrm{p}}-\bar{y}\right)^{2}\right] & =496.63 \\
\Sigma(y-\bar{y})^{2} & =560.5
\end{aligned}
$$

\section{TABLE VIII.}


Variance between Arrays due to :-

Linear regression

Deviations from regression

Total

\section{TABLE IX}

$\begin{array}{ccc}\begin{array}{c}\text { Degrees of } \\ \text { Freedom. }\end{array} & \begin{array}{c}\text { Sum of } \\ \text { Squares. }\end{array} & \begin{array}{c}\text { Mean. } \\ \text { Square. }\end{array} \\ 1 & 485 \cdot 0 & \ldots \\ 14 & 11 \cdot 6 & 0 \cdot 83 \\ - & - & \\ 15 & 496 \cdot 6 & \end{array}$

TABLE X.

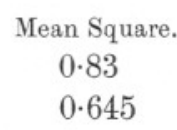

$\frac{1}{2} \mathrm{Log}$.

$-0.093$

$-0 \cdot 219$

\section{Difference $(z) \quad=0 \cdot 126$}

Thus $z$ is $0 \cdot 126$, and since the 5 per cent point is about $0 \cdot 29(2$, p. 212$)$, there is absolutely no significant departure from linear regression.

(b) Females.

TABLE XI.

$\begin{array}{rccc} & \text { Estimate. } & \begin{array}{c}\text { Correction } \\ \text { for Mean. }\end{array} & \begin{array}{c}\text { Corrected } \\ \text { Estimate. }\end{array} \\ \Sigma(y-\bar{y})^{2} & 714 & -\frac{32^{2}}{120} & 705 \cdot 5 \\ \Sigma(x-\bar{x})^{2} & 1901 & -\frac{\left(-27^{2}\right)}{120} & 1894 \cdot 9 \\ \Sigma(x-\bar{x})(y-\bar{y}) & 986 & +\frac{32 \times 27}{120} & 993 \cdot 2\end{array}$

From Table VI,

Sum of Product in first 21 arrays $=558.54$

Products in final array

$=8.53$

From Table XI,

$$
\begin{aligned}
\Sigma\left[n_{\mathrm{p}}\left(\bar{y}_{\mathrm{p}}-\bar{y}\right)^{2}\right] & =550.01 \\
\Sigma(y-\bar{y})^{2} & =705.5
\end{aligned}
$$

\begin{tabular}{|c|c|c|c|}
\hline $\begin{array}{l}\text { Variance. } \\
\text { Between Arrays }\end{array}$ & $\begin{array}{c}\text { Degrees of } \\
\text { Freedom. } \\
20\end{array}$ & $\begin{array}{c}\text { Sum of } \\
\text { Squares. } \\
550 \cdot 0\end{array}$ & $\begin{array}{c}\text { Mean } \\
\text { Square } \\
\ldots\end{array}$ \\
\hline Within Arrays & 99 & $155 \cdot 5$ & 1.571 \\
\hline Total & 119 & $705 \cdot 5$ & \\
\hline $\begin{array}{r}\Sigma \\
\therefore \quad[\Sigma \\
\therefore \quad\end{array}$ & $\begin{array}{l}\Sigma(x-x)^{2} \\
-\bar{x})(y-\bar{y}) \\
-\bar{x})(y-\bar{y})]^{2} \\
(x-\bar{x})^{2}\end{array}$ & $\begin{array}{l}894 \cdot 9 \\
993 \cdot 2 \\
93 \cdot 2)^{2} \\
894 \cdot 9\end{array}$ & \\
\hline
\end{tabular}

\section{TABLE XII.}




\section{TABLE XIII.}

Variance between
Arrays due to :-
Linear regression
Deviations from regression

Total

$\begin{array}{ccc}\begin{array}{c}\text { Degrees of } \\ \text { Freedom. }\end{array} & \begin{array}{c}\text { Sum of } \\ \text { Squares. }\end{array} & \begin{array}{c}\text { Mean } \\ \text { Square. }\end{array} \\ 1 & 520 \cdot 6 & \ldots \\ 19 & 29 \cdot 4 & 1 \cdot 547 \\ - & - & \\ 20 & 550 \cdot 0 & \end{array}$

\section{TABLE XIV.}

$\begin{array}{ccc}\text { Mean Square. } & \text { Natural Log. } & \frac{1}{2} \text { Log. } \\ 1.547 & 0.436 & 0 \cdot 218 \\ 1.571 & 0.452 & 0.226 \\ & & \\ & \text { Difference }(z) & =-0.008\end{array}$

The probability that any departures from the female regression line are significant is therefore infinitesimal. 
